\title{
UPAYA PENINGKATAN KEAKTIFAN DAN HASIL BELAJAR SEJARAH INDONESIA MELALUI METODE 3M (MEMBACA, MENULIS PERTANYAAN DAN MENJAWAB PERTANYAAN) PADA SISWA KELAS X SMK NEGERI 1 PANJI SEMESTER GANJIL TAHUN AJARAN 2019/2020
}

\author{
Dian Agustina ${ }^{1}$ \\ ${ }^{1}$ SMK Negeri 1 Panji \\ Correspondence Email: $\underline{\text { d_agustin@gmail.com }}$
}

Received: Apr 25, $2020 \quad$ Revised: Apr 29, $2020 \quad$ Accepted: Apr 4, 2020

\begin{abstract}
ABSTRAK
Metode 3M (membaca, menulis pertanyaan dan menjawab pertanyaan) adalah komposisi terpadu membaca (memahami isi materi) dan menulis pertanyaan serta menjawab pertanyaan (mengerjakan soal) secara koperatif -kelompok. Sintaksnya adalah: membentuk kelompok heterogen 4 orang, guru memberikan soal materi sesuai dengan materi bahan ajar, siswa bekerja sama kemudian menuliskan hasil kolaboratifnya, presentasi hasil kelompok, refleksi.

Desain penelitian dalam penelitian ini adalah PTK dengan berkolaborasi dengan guru yang ditetapkan 2 siklus. Dalam PTK ada 4 tahapan yaitu perencanaan, tindakan, observasi dan refleksi. Data primer dengan menggunakan tes ulangan dan observasi dengan di checklist, dan data sekunder dengan wawancara. Peneliti menggunakan keharusan nilai sasaran atau KKM (Kriteria Ketuntasan Minimal) menentukan kriteria sukses untuk menganalisis data

Berdasarkan hasil penelitian pada bab IV dapat disimpulkan sebagai berikut: penerapan metode $3 \mathrm{M}$ (membaca, menulis pertanyaan dan menjawab pertanyaan) dapat meningkatkan aktivitas belajar mencapai $26 \%$ mata pelajaran sejarah Indonesia pokok bahasan pokok bahasan teori masuknya agama dan kebudayaan hindu budha di Indonesia kelas X SMK Negeri 1 Panji semester ganjil tahun ajaran 2019/2020. Penerapan metode 3M (membaca, menulis pertanyaan dan menjawab pertanyaan) dapat meningkatkan hasil belajar mencapai $22 \%$ mata pelajaran sejarah Indonesia pokok bahasan pokok bahasan teori masuknya agama dan kebudayaan hindu budha di Indonesia kelas X SMK Negeri 1 Panji semester ganjil tahun ajaran 2019/2020.
\end{abstract}

Kata Kunci: Keaktifan dan Hasil Belajar Sejarah Indonesia, Metode 3M

\section{PENDAHULUAN}

Budaya literasi yang sangat rendah sehingga hasil dan motivasi siswa rendah, dalam kelompok kecil, para siswa diberi suatu teks atau bacaan (materi), kemudian siswa latihan membaca atau saling membaca, memahami ide pokok, saling merevisi, dan menulis ikhtisar materi, atau memberikan tanggapan terhadap isi materi, atau untuk mempersiapkan tugas tertentu dari guru. Indikatornya adalah membaca isi materi, kooperatif dan menulis (mengerjakan soal) 
Berdasarkan uraian di atas maka penelitian ini mengambil judul "Upaya peningkatan keaktifan dan hasil belajar sejarah Indonesia melalui metode 3M (membaca, menulis pertanyaan dan menjawab pertanyaan) pada siswa kelas X SMK Negeri 1 Panji semester ganjil tahun ajaran 2019/2020 (pokok bahasan teori masuknya agama dan kebudayaan hindu budha di Indonesia)"

\section{METODE DAN PROSEDUR PENELITIAN}

Penelitian ini adalah penelitian tindakan kelas (PTK) yang bertujuan untuk meningkatkan hasil belajar siswa dalam proses pembelajaran pada bidang study Ilmu pengetahuan sosial. Penelitian tindakan ini menggunakan dua siklus, masing-masing siklus terdiri dari empat tahap, yaitu merencanakan, melakukan tindakan, mengamati dan merefleksi. Menurut Siklus PTK model Kemmis dan Taggart (Depdiknas 2004:18), keempat fase dalam satu siklus sebuah PTK seperti ditunjukkan dengan gambar berikut:

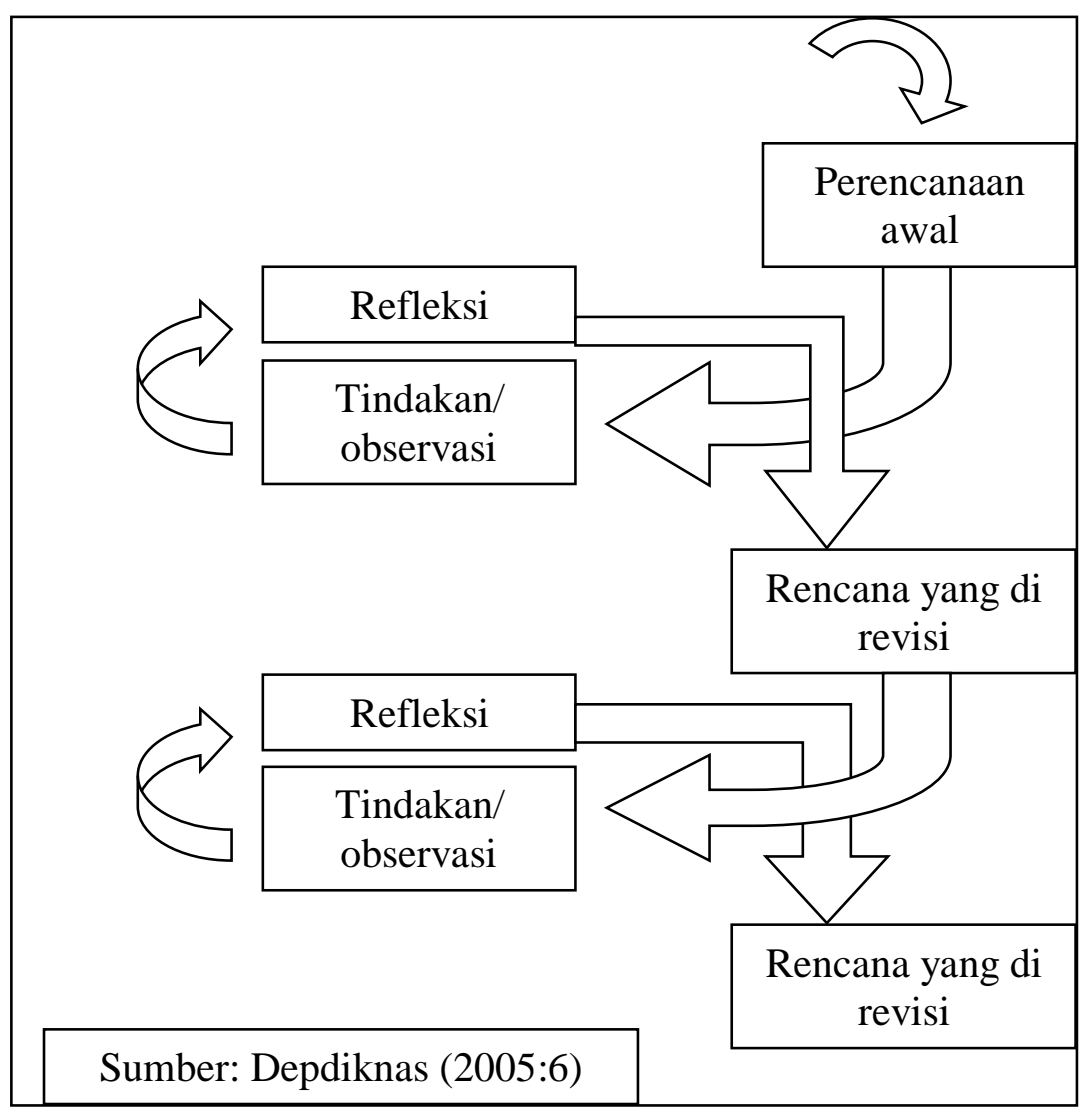

\section{PENELITIAN TINDAKAN MODEL KEMMIS DAN TAGGART}

Sesuai dengan gambar spiral penelitian tindakan kelas diatas penelitian ini terdiri atas empat fase yaitu perencanaan, tindakan, observasi dan refleksi. 


\section{Perencanaan}

Tahap ini merupakan tahap merencanakan segala sesuatu yang akan dilakukan dalam penelitian. Kegiatan yang dilakukan dalam tahap perencanaan tiap siklus adalah sebagai berikut:

1. Menyusun rencana pembelajaran pada pokok bahasan yang akan dibahas

2. Mempersiapkan gambar dan perlengkapan dalam pokok bahasan yang akan dibahas

3. Mempersiapkan soal sebagai bahan diskusi baik diluar kelas maupun didalam kelas

4. Mempersiapkan soal tes ulangan harian untuk siswa

5. Mempersiapkan tugas pekerjaan rumah untuk siswa

6. Mempersiapkan rangkuman materi untuk dibagikan kepada siswa

7. Proses belajar mengajar dibagi menjadi tiga tahap yaitu:

a. Pendahuluan, guru memberikan apersepsi tentang pentingnya pembelajaran Ilmu pengetahuan sosial yang akan dibahas

b. Kegiatan inti, guru mendampingi dan membimbing siswa dalam melakukan kegiatan Metode 3M (membaca, menulis pertanyaan dan menjawab pertanyaan). Kegiatan peer tutorial dimulai dari siswa mengajukan dugaan sementara, melakukan observasi, dan diskusi untuk mencapai pengambilan kesimpulan

c. Kegiatan penutup

8. Mempersiapkan daftar pertanyaan untuk mewawancarai siswa mengenai tanggapannya terhadap penerapan Metode 3M (membaca, menulis pertanyaan dan menjawab pertanyaan).

9. Membuat lembar observasi yang digunakan peneliti untuk mengamati hasil belajar siswa.

\section{Tindakan}

Pada tahap ini kegiatan yang dilaksanakan adalah melakukan tindakan berdasarkan pada perencanaan yang telah dibuat. Peneliti bertindak sebagai guru. Penelitian ini dilakukan dalam dua siklus dengan rincian tiap siklus sebagai berikut:

\section{Kegiatan pendahuluan}

Guru memberikan apersepsi kepada siswa sesuai dengan materi yang akan dibahas

\section{Kegiatan Inti}

Pada kegiatan ini peneliti menerapkan kegiatan Metode 3M (membaca, menulis pertanyaan dan menjawab pertanyaan) yang terdiri dari membagi siswa menjadi 4 atau berpasangan siswa kemudian menentukan siswa yang berhak untuk menjadi tutor dalam setiap kelompok adapun langkah-langkah sebagai berikut: 
Langkah I: Guru menjelaskan tentang penerapan Metode 3M (membaca, menulis pertanyaan dan menjawab pertanyaan). Guru menjelaskan dengan memberikan contoh cara membaca isi soal teori masuknya agama dan kebudayaan hindu budha di Indonesia kemudian siswa mengerjakan soal serta siswa menuliskan hasil presentasi.

Langkah II: Membentuk siswa menjadi 4 atau berpasangan siswa dalam setiap kelompok dengan memperhatikan kriteria daya serap siswa rendah, sedang dan tinggi. Kemudian guru memberikan tugas kelompok agar dapat dibahas dengan teman sebayanya (jika berpasangan).

Langkah III: Guru memberikan motivasi kepada siswa agar dapat mampu menyelesaikan soal teori masuknya agama dan kebudayaan hindu budha di Indonesia. Guru bersama siswa berdiskusi tentang apa yang masih kurang dipahami tentang materi yang telah dijelaskan pada awal pertemuan.

Langkah IV: Memberikan kesempatan kepada kelompok untuk dapat mempresentasikan hasil diskusinya

\section{Kegiatan penutup}

Guru memberikan tugas pelajaran rumah melalui LKS, pemberian tugas melalui LKS dimaksudkan untuk menyeimbangkan pengetahuan. Siswa yang telah didapat melalui diskusi dalam pembelajaran metode 3M (membaca, menulis pertanyaan dan menjawab pertanyaan).

\section{Refleksi}

Tahap refleksi ini merupakan tahap yang dilakukan peneliti untuk menilai hasil kegiatan belajar peserta didik dari tindakan yang telah dilaksanakan. Peneliti melakukan refleksi dengan cara mengevaluasi hasil belajar peserta didik dengan penerapan Metode 3M (membaca, menulis pertanyaan dan menjawab pertanyaan) yang telah dilaksanakan. Dengan melakukan refleksi peneliti dapat mengetahui kekurangan kegiatan belajar mengajar yang dilakukan oleh peneliti sehingga dapat digunakan untuk menentukan tindakan perbaikan pada siklus berikutnya.

Untuk mengkategorikan tingkah laku siswa selama pelaksanaan tindakan, peneliti menggunakan lembar observasi berdasarkan Sukarni (2001:429) tentang aspek yang harus diamati dalam penggunaan Model Pembelajaran Metode 3M (membaca, menulis pertanyaan dan menjawab pertanyaan) Untuk mengetahui prosentase Keterlibatan siswa dalam belajar kelompok, menulis dan membaca. 
Sedangkan untuk mengukur ketuntasan dalam belajar siswa dapat menggunakan rumus

$$
\mathrm{P}=\frac{n}{N} x 100 \%
$$

Keterangan $\mathrm{P}=$ Prosentase ketuntasan

$\mathrm{n}=$ Jumlah siswa yang tuntas

$\mathrm{N}=$ Jumlah seluruh siswa (Depdiknas, 2004:14-17)

Setelah nilai hasil belajar dipresentasikan kemudian dicari standar ketuntasan ini didasarkan pada standar yang ditetapkan oleh sekolah tersebut yaitu daya serap siswa secara individu dan klasikal standar tersebut yaitu:

\section{Daya serap perseorangan}

Seorang siswa dikatakan telah memenuhi KKM bila mencapai $\geq 75 \%$ atau nilai $\geq 75$.

\section{Daya serap klasikal}

Suatu kelas dikatakan telah memenuhi standar ketuntasan belajar di kelas tersebut telah mencapai $\geq 85 \%$ dari jumlah siswa yang telah mencapai nilai $\geq 75$. (Kurikulum dari SMA Negeri 1 Panji Situbondo )

Untuk menghitung jumlah skor digunakan pedoman sebagai berikut:

$\mathrm{P}=\frac{N}{M} \times 100 \%$

Keterangan: $\mathrm{P}$ : Persentase

$\mathrm{N}$ : Skor yang diperoleh peserta didik

M: Skor maksimal

Kategori Penilaian Keaktifan Peserta Didik Secara Individual

\begin{tabular}{|l|c|}
\hline \multicolumn{1}{|c|}{ Prosentase } & Kriteria \\
\hline $\mathrm{P} \geq 80$ & Sangat aktif \\
$70 \leq \mathrm{P}<80$ & Aktif \\
$60 \leq \mathrm{P}<70$ & Cukup aktif \\
$\mathrm{P}<60$ & Tidak aktif \\
\hline
\end{tabular}

Sumber: Ningtiash (2007)

Kriteria Hasil Belajar

\begin{tabular}{|c|c|}
\hline Rentangan Skor & Kategori Hasil Belajar \\
\hline $80-100$ & Sangat Baik \\
\hline $70-79$ & Baik \\
\hline
\end{tabular}




\begin{tabular}{|c|c|}
\hline $60-69$ & Cukup Baik \\
\hline $50-59$ & Kurang Baik \\
\hline $0-49$ & Sangat Kurang Baik \\
\hline
\end{tabular}

\section{HASIL PENELITIAN DAN PEMBAHASAN}

\section{Hasil Penelitian Prasiklus}

Guru meminta izin kepada Kepala Sekolah. Melakukan diskusi dengan guru untuk menentukan kelas mana yang ingin dilakukan perbaikan. Dari hasil diskusi akhirnya ditentukan kelas yang akan dilakukan perbaikan adalah kelas X BDP-1 dengan alasan nilai rata-rata ulangan sub pokok bahasan teori masuknya agama dan kebudayaan hindu budha di Indonesia di kelas tersebut belum memenuhi KKM yakni 50\% atau 18 siswa yang tuntas. Hasil observasi siswa menunjukkan bahwa siswa masih kurang berminat untuk membaca buku sehingga siswa kurang paham akan soal yang diberikan oleh guru.

Siswa masih kurang mampu untuk membaca maka perlu adanya model pembelajaran yang mampu mengatasi kesulitan belajar siswa khususnya siswa kelas X BDP-1. Usaha yang dilakukan guru adalah telah menyediakan bacaan yang membuat siswa menarik dengan memberikan gambar namun tidak berhasil siswa kurang terlibat langsung dalam pembelajaran bahkan dalam mengerjakan soal masih cenderung mencontek hasil pekerjan teman. Berdasarkan latar belakang itulah peneliti memiliki inisiatif untuk menerapkan Metode 3M (membaca, menulis pertanyaan dan menjawab pertanyaan) yang mampu memberikan pemahaman dalam membaca dan ketelitian dalam membaca soal dengan memberikan garis dan merangkum suatu materi yang dianggap sulit serta memberikan kesempatan kepada siswa untuk lebih aktif dalam kelas tanpa adanya bimbingan guru.

\section{Hasil Penelitian Siklus I}

Berdasarkan perencanaan yang telah dipersiapkan sebelumnya, maka dilaksanakan tindakan penelitian dan observasi. Tindakan penelitian ini dilakukan pada sub pokok bahasan Teori masuknya agama dan kebudayaan hindu budha di Indonesia, yang terdiri dari tindakan pertemuan pertama dan kedua serta pelaksanaan ulangan harian. Sedangkan observasi dilakukan selama tindakan pembelajaran berlangsung dengan menerapkan pembelajaran dengan menggunakan metode 3M (membaca, menulis pertanyaan dan menjawab pertanyaan)

1) Kegiatan Awal

a) Guru memulai kegiatan belajar-mengajar dengan menjelaskan tujuan pembelajaran. 
2) Kegiatan Inti

a) Dengan tanya jawab, siswa diarahkan untuk dapat menemukan contoh teori masuknya agama dan kebudayaan hindu budha di Indonesia.

b) Guru menjelaskan teori masuknya agama dan kebudayaan hindu budha di Indonesia.

c) Guru menunjukkan contoh teori masuknya agama dan kebudayaan hindu budha di Indonesia yang telah dibuat

d) Siswa dapat menyebutkan dua macam cara yang dijalankan oleh manusia dalam melakukan teori masuknya agama dan kebudayaan hindu budha di Indonesia

e) Siswa dibentuk kelompok 6 siswa dalam satu kelompok

f) Guru memberikan teks informasi (koran, majalah) tentang kegiatan yang terjadi di masyarakat dalam melakukan teori masuknya agama dan kebudayaan hindu budha di Indonesia kemudian siswa diharapkan dapat membaca sepintas tentang informasi tersebut

g) Melalui media teks bacaan guru meminta siswa untuk membuat pertanyaan dari teks bacaan

h) Siswa diharapkan dapat menjawab pertanyaan yang telah disusun dengan Menemukan kata kunci dalam artikel tersebut

i) Siswa diharapkan dapat mengingat kembali dengan mengerjakan latihan soal pada LKS tanpa melihat bacaan

j) Siswa mampu mempresentasikan hasil jawaban LKS di depan kelas

k) Guru memberikan kesempatan kepada siswa untuk membaca ulang materi yang dipelajari dan apabila ada siswa yang kurang mengerti dapat bertanya kepada guru

1) Siswa diberi penguatan dan penghargaan atas kinerja siswa

3. Kegiatan Akhir

m) Guru menutup pembelajaran dengan penugasan. Siswa diminta untuk mengidentifikasikan teori masuknya agama dan kebudayaan hindu budha di Indonesia. Tugas dikumpulkan pada pertemuan berikutnya!

\section{Observasi}

Kegiatan observasi dimulai sampai pelajaran selesai untuk mengamati aktivitas belajar siswa dan aktivitas guru selam proses belajar mengajar berlangsung. Hasil observasi aktivitas siswa dapat dilihat pada tabel berikut: 
Hasil observasi Aktivitas Belajar Siswa Siklus 1

\begin{tabular}{|c|c|c|}
\hline Kategori Aktivitas & Frekuensi (F) & Persentase \% \\
\hline Sangat Aktif & 10 & $30 \%$ \\
\hline Aktif & 11 & $28 \%$ \\
\hline Cukup Aktif & 15 & $42 \%$ \\
\hline Kurang Aktif & 0 & 0 \\
\hline Sangat Kurang Aktif & 0 & 0 \\
\hline Jumlah & 36 & $100 \%$ \\
\hline
\end{tabular}

Tidak hanya siswa saja dalam penelitian ini disalahkan, namun guru kurang mampu memberikan motivasi kepada siswa sehingga banyak siswa kurang percaya diri dengan hasil jawaban yang dikerjakan sendiri, sehingga banyak yang terjadi pada saat pembelajaran antara lain siswa banyak yang menyontek hasil pekerjaan teman dan bahkan ada siswa yang membawa catatan kecil untuk menjawab soal yang diberikan guru. Maka untuk memperbaiki hal tersebut membutuhkan suatu perbaikan pada siklus berikutnya dengan memperbaiki pada kegiatan ini pada siklus 2.

Ketuntasan belajar siswa kelas X BDP-1-A Siklus 1

\begin{tabular}{|l|c|c|}
\hline Kategori Hasil Belajar & Frekuensi (F) & Persentase (\%) \\
\hline Sangat baik & 16 & $44 \%$ \\
\hline Baik & 20 & $56 \%$ \\
\hline Cukup Baik & 0 & $0 \%$ \\
\hline Kurang Baik & 0 & $3 \%$ \\
\hline Sangat Kurang Baik & 0 & $0 \%$ \\
\hline Jumlah & 36 & 100 \\
\hline
\end{tabular}

\section{Hasil Penelitian Siklus II}

Berdasarkan rencana perbaikan yang telah disiapkan dengan lebih matang, yang berpedoman atas kekurangan yang ada pada siklus I. Tahapan tindakan pada siklus II sama dengan tindakan pada siklus I. tindakan ini merupakan perbaikan pada siklus I dimana guru dan peneliti berupaya untuk meningkatkan aktivitas dan hasil belajar siswa pada sub pokok bahasan yang sama dengan materi siklus I, tindakan siklus II terdiri dari 1 kali pertemuan dan 1 kali pertemuan observasi dilakukan selama tindakan pembelajaran berlangsung. 
Pembelajaran dilakukan dengan berpedoman pada rencana pembelajaran 4 . Pembelajaran pada pertemuan pertama berlangsung $2 \times 45$ menit, yaitu pukul 07.30-09.00 WIB dengan sub pokok bahasan Teori masuknya agama dan kebudayaan hindu budha di Indonesia.

1) Kegiatan Awal

a) Guru mengingatkan materi yang lalu dengan membahas tugas yang telah dikerjakan.

2) Kegiatan Inti

a) Dengan tanya jawab, siswa diarahkan untuk menemukan contoh teori masuknya agama dan kebudayaan hindu budha di Indonesia yang dilakukan manusia.

b) Dengan penjelasan guru, siswa dapat mengidentifikasikan teori masuknya agama dan kebudayaan hindu budha di Indonesia secara rasional.

c) Guru membagi kelas menjadi kelompok-kelompok kecil yang beranggotakan 4-5 orang siswa.

d) Guru meminta siswa untuk mengumpulkan artikel.

e) Guru membimbing siswa untuk mampu menggaris bawahi hal-hal yang penting dengan diberi waktu hanya 10 menit untuk membaca artikel tersebut

f) Dari bacaan yang ditandainya siswa mampu membuat pertanyaan

g) Siswa mampu mencari jawabannya dari pertanyaan yang disusun dengan benar

h) Siswa mengerjakan LKS tanpa melihat artikel yang dibacanya

i) Guru mendorong siswa untuk bekerja dalam kelompok, serta membimbing siswa untuk mengerjakan LKS sesuai dengan prosedur metode 3M (membaca, menulis pertanyaan dan menjawab pertanyaan),

j) Guru membimbing siswa agar mampu mengerjakan latihan-latihan soal yang ada di LKS sesuai dengan langkah-langkah yang diberikan oleh guru, serta siswa dapat menulis pokok-pokok materi yang ada dalam bacaan.

k) Guru meminta salah satu kelompok untuk mempresentasikan hasil kerjanya.

1) Guru memandu kegiatan presentasi dan diskusi.

m) Setelah selesai kegiatan diskusi, guru membantu siswa untuk melakukan refleksi serta menyimpulkan kegiatan yang telah diselesaikan. Kemudian guru melaksanakan evaluasi.

3) Kegiatan Akhir

a) Guru menutup pembelajaran dengan penugasan.

Guru memberikan informasi kepada siswa untuk lebih giat belajar karena akan dilaksanakan ulangan harian. 


\section{Observasi}

Kegiatan observasi sampai pelajaran selesai untuk mengamati aktivitas belajar siswa dan aktivitas guru selama proses belajar mengajar berlangsung.

Aktivitas Belajar kelas X BDP-1-A Prasiklus Siklus dan Siklus 2

\section{Refleksi}

\begin{tabular}{|l|c|c|c|}
\hline Kategori Hasil Belajar & Prasiklus & Siklus 1 & Siklus 2 \\
\hline Sangat Aktif & $9 \%$ & $30 \%$ & $83 \%$ \\
\hline Aktif & $3 \%$ & $28 \%$ & $17 \%$ \\
\hline Cukup Aktif & $44 \%$ & $42 \%$ & $0 \%$ \\
\hline Kurang Aktif & $44 \%$ & 0 & $0 \%$ \\
\hline Sangat Kurang Aktif & 0 & 0 & $\%$ \\
\hline
\end{tabular}

Berdasarkan analisis observasi aktivitas belajar siswa dan hasil belajar siswa dari hasil nilai ulangan harian serta mewawancarai yang dilakukan kajian terhadap siklus II, selama kegiatan berlangsung masih ada siswa yang kurang mampu memahami bacaan dengan cepat dan masih ada siswa yang bergurau sendiri pada saat diskusi berlangsung sehingga mereka tidak memahami betul materi yang diajarkan serta tidak mau bertanya bila mengalami kesulitan. Tetapi suasana siklus tidak seramai pada saat siklus I karena guru sudah lancar dalam metode $3 \mathrm{M}$ (membaca, menulis pertanyaan dan menjawab pertanyaan) sehingga guru bisa melakukan pengelolaan kelas dengan baik dan siswa tidak merasa bingung dengan pembelajaran ini. Hasil observasi aktivitas belajar siswa dapat dilihat pada tabel berikut:

Ketuntasan belajar siswa kelas X BDP-1-A Prasiklus, Siklus 1 dan 2

\begin{tabular}{|l|c|c|c|}
\hline Kategori Hasil Belajar & Prasiklus & Siklus 1 & Siklus 2 \\
\hline Sangat baik & $11 \%$ & $44 \%$ & $83 \%$ \\
\hline Baik & $25 \%$ & $56 \%$ & $17 \%$ \\
\hline Cukup Baik & $64 \%$ & $0 \%$ & $9 \%$ \\
\hline Kurang Baik & $0 \%$ & $3 \%$ & 0 \\
\hline Sangat Kurang Baik & $0 \%$ & $0 \%$ & 0 \\
\hline Jumlah & $100 \%$ & $100 \%$ & $100 \%$ \\
\hline
\end{tabular}

Berdasarkan tabel tersebut ada peningkatan pada siklus 1, sebesar 22\% dari kegiatan prasiklus. Kegiatan prasiklus mencapai kategori tidak aktif disebabkan guru masih kurang mampu menggunakan model pembelajaran inovatif sedangkan pada siklus 2 guru menerapkan model pembelajaran tipe 3M (membaca, menulis pertanyaan dan menjawab pertanyaan) namun kondisi kelas masih ramai dan aktivitas belajar siswa terganggu sehingga mencapai 
persentase sebesar $65 \%$ atau cukup aktif kemudian guru mengadakan perbaikan dengan lebih mempersiapkan diri menerapkan model pembelajaran tipe 3M (membaca, menulis pertanyaan dan menjawab pertanyaan) sehingga mencapai $84 \%$ pada siklus 2 .

\section{Refleksi}

Berdasarkan analisis observasi aktivitas belajar siswa dan hasil belajar siswa dari hasil nilai ulangan harian serta mewawancarai yang dilakukan kajian terhadap siklus II, selama kegiatan berlangsung masih ada siswa yang kurang mampu memahami bacaan dengan cepat dan masih ada siswa yang bergurau sendiri pada saat diskusi berlangsung sehingga mereka tidak memahami betul materi yang diajarkan serta tidak mau bertanya bila mengalami kesulitan. Tetapi suasana siklus tidak seramai pada saat siklus I karena guru sudah lancar dalam metode 3M (membaca, menulis pertanyaan dan menjawab pertanyaan) sehingga guru bisa melakukan pengelolaan kelas dengan baik dan siswa tidak merasa bingung dengan pembelajaran ini. Hasil observasi aktivitas belajar siswa dapat meningkat.

\section{KESIMPULAN}

Berdasarkan hasil penelitian dan pembahasan pada bab IV dapat disimpulkan sebagai berikut: Penerapan metode 3M (membaca, menulis pertanyaan dan menjawab pertanyaan) dapat meningkatkan aktivitas belajar mencapai $26 \%$ mata pelajaran sejarah Indonesia pokok bahasan pokok bahasan teori masuknya agama dan kebudayaan hindu budha di Indonesia kelas X SMK Negeri 1 Panji semester ganjil tahun ajaran 2019/2020. Penerapan metode 3M (membaca, menulis pertanyaan dan menjawab pertanyaan) dapat meningkatkan hasil belajar mencapai $22 \%$ mata pelajaran sejarah Indonesia pokok bahasan pokok bahasan teori masuknya agama dan kebudayaan hindu budha di Indonesia kelas X SMK Negeri 1 Panji semester ganjil tahun ajaran 2019/2020.

Berdasarkan pada kesimpulan di atas, maka kami menyarankan khususnya kepada : Bagi guru, sebagai alternatif model pembelajaran untuk meningkatkan kualitas proses belajar mengajar khususnya pada mata pelajaran sejarah Indonesia. Bagi Kepala Sekolah, yang terkait, agar hasil penelitian ini dapat dijadikan masukan positif dalam rangka peningkatan mutu pendidikan, khususnya pembelajaran sejarah Indonesia. 


\section{DAFTAR PUSTAKA}

Ali, Muhammad. 1993. Strategi Penelitian Pendidikan. Bandung: Angkasa.

Anna Marie Farnish. 2006. Cooperative Integrated Reading and Composition (CIRC) Reading. Baltimore: Center for Social Organization of Schools, The Johns Hopkins University. Tersedia di:

http://www.ed.gov/pubs/EPTW/eptw4/eptw4c.html [April 2006]

Arikunto, Suharsimi. 2002. Prosedur Penelitian. Jakarta: Rineka Praktek

Arifin, Zaenal. 1991. Evaluasi Instruksional: prinsip-teknik-prosedur. Bandung: Remaja Rosdakarya.

Ibrahim, Muslimin dkk. 2001. Pembelajaran Kooperatif. Surabaya: UNESA

Junaidi, Syamsul dan Eko Siswono. 2004. Matematika untuk SMP Kelas VII. Semarang: Esis.

Lie, Anita. 2004. Cooperative Learning: Mempraktikkan Cooperative Learning di Ruangruang Kelas. Jakarta: Grasindo.

Sardiman. 2001. Interaksi dan Motivasi Belajar Mengajar. Jakarta: PT Raja Grafindo Persada.

Slavin, Robert E. 1995. Cooperative Learning: Theory, Research and Practice. Second Edition. Boston: Ally and Bacon.

Sudjana. 2002. Metode Statistika. Bandung: Tarsito.

Suharyono, T. dkk. 1996. Strategi Belajar Matematika. AMP Matematika Jakarta: konsultan dan tim pengembangan PKG matematika. Dirjen Dikdasmen Depdikbud.

Suherman, Erman dkk. 2003. Satrategi Pembelajaran Matematika Kontemporer. Bandung: JICA Universitas Pendidikan Indonesia

Suryabrata, Sumadi. 1998. Metodologi Penelitian. Jakarta: Rajawali

Suyitno, Amin. 2004. Dasar-dasar dan Proses Pembelajaran Matematika I. Semarang: Universitas Negeri Semarang.

Suyitno, Amin. 2005. Mengadopsi Model Pembelajaran Cooperative Learning Tipe CIRC (Cooperative Integrated Reading and Composition) dalam Meningkatkan Ketrampilan Siswa Menyelesaikan Soal Cerita. Makalah Seminar Nasional UNNES, Desember 2005 (tidak diterbitkan) 